\title{
Negara Islam Indonesia: Konsepsi Shajarah Tayyibah dalam Konstruk Negara Islam
}

\author{
Syofyan Hadi ${ }^{1}$
}

\begin{abstract}
This article aims to prove that the interpretation of the verses of the Qur'an by using a rational approach to the political vision has a tendency to release an understanding of the text from its real context. This often makes an interpretation of these verses that are interpreted to justify and legalize the ideology that is being held.

Based on the study of the works of supporters and leaders of the Negara Islam Indonesia (NII), this study proves that their interpretation is so far detached from the historical context of the Qur'an. More than once, the article insists, one verse is interpreted too far to legalize their aspiration without giving any reference to the traditions which are related to the context of the Qur'an, and the opinions of the previous 'ulamā' and interpreters of the Qur'an, who are considered more authoritative in giving an interpretation to the verses of the Qur'ān.
\end{abstract}

\begin{abstract}
Abstrak
Kajian ini bertujuan membuktikan bahwa penafsiran terhadap ayat-ayat al-Qur'ān dengan menggunakan pendekatan logis bervisi politis (ra'yun siyāsiyun) memiliki kecenderungan untuk melepaskan pemahaman teks dari konteks yang sesungguhnya. Penafsiran ini seringkali menjadikan ayat-ayat yang ditafsirkan itu untuk membenarkan serta melegalkan ideologi yang sedang diperjuangan.

Berdasarkan atas kajian terhadap karya-karya pendukung dan pimpinan Negara Islam Indonesia (NII), kajian ini membuktikan bahwa penafsiran mereka terlepas begitu jauh dari kontekstual ayat yang ditafsirkan. Tidak jarang, suatu ayat kemudian diseret terlalu jauh demi membenarkan cita-cita perjuangan mereka, tanpa merujuk kepada riwayat-riwayat terkait konteks ayat tersebut, pendapat-pendapat ulama atau para mufassir terdahulu yang dianggap lebih otoritatif dalam memberikan tafsiran terhadap suatu ayat-ayat al-Qur'ān.
\end{abstract}

Keywords: Shajarah tayyibah, manhaj nubuwwah, Rububiyyah, Mulkiyyah, Ulūhiyyah

1 Dosen Fakultas Adab IAIN Imam Bonjol, Padang. E-mail: hadi_syofyan@yahoo.com 


\section{Pendahuluan}

Salah satu peristiwa penting yang meninggalkan bekas dalam catatan sejarah negeri ini adalah berdirinya Negara Islam Indonesia (NII) di awal masa kemerdekaan tepatnya tanggal 7 Agustus 1949 hanya berselang 4 tahun setelah diproklamasikannya Negara Kesatuan Republik Indonesia (NKRI). ${ }^{2}$ Topik ini memang selalu dan akan tetap menarik untuk diperbincangkan, lengkap dengan segala pendapat para ahli maupun saksi-saksi sejarah terhadapnya, sebab faktanya adalah bahwa dalam buku pelajaran sejarah di bangku sekolah maupun yang tersimpan di dalam arsip nasional Pemerintah Indonesia bahwa kelompok ini dianggap sebagai kaum pemberontak dan separatis serta pengacau keamanan dan stabilitas Negara. ${ }^{3}$ Walaupun fakta itu dianggap sebagai kebohongan oleh sebagian pihak, termasuk di antaranya komunitas yang mengaku sebagai Warga Negara Islam Indonesia dan para simpatisannya.

Negara Islam Indonesia adalah sebuah gerakan kelompok Islam yang berjuang untuk menegakkan negara Islam dengan visi membangun negara seperti yang pernah dibangun oleh Rasulullah saw. pada periode Madinah. Negara Madinah dianggap prototipe negara ideal untuk membangun tatanan masyarakat yang adil, makmur dan berperadaban tinggi. Umat Islam tidak layak hidup dalam tatanan pemerintahan kafir atau paling tidak dalam tatanan negara yang diadopsi dari sistem kafir.

Untuk memperkokoh dan melegitimasi ide-ide mereka, tentu saja alQur'ān dan Hadis Nabi saw. menjadi dasar pijakan, namun ayat-ayat maupun hadis yang mereka "catut" ditafsirkan dan dipahami sesuai sudut pandang dan perspektif mereka. Tidak jarang kemudian muncul kesan penafsiran yang terlalu dipaksakan terhadap isi dan kandungan suatu ayat al-Qur'ān ataupun hadis Nabi saw. Setidaknya kesan itulah yang terlihat ketika mereka menfasirkan tentang

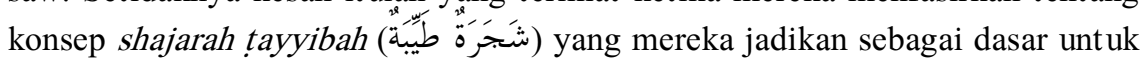
mengatakan adanya kewajiban umat Islam untuk membangun dan mendirikan negara Islam.

2 Terkait asal mula gerakan NII ini juga telah disinggung oleh Felix Heiduk, "Between a Rock and Hard Place: Radikal Islam in Post-Soeharto Indonesia", International Journal of Conflict and Violence, Vol 6 (1) (2012), 30.

${ }^{3}$ lihat misalnya yang dikatakan Paul J. Carnegie, "Political Islam and Democratic Change in Indonesia" Journal of Asian Social Science Vol. 4, No 11 (November 2008), 3. Hal yang sama juga disinggung oleh Azyumardi Azra, "Bali and Southeast Asian Islam: Debunking the Myths", di Kumar Ramakrishna dan See Seng Tan (Editor), After Bali: The Threat of Terrorism in Southeast Asia (Singapore: Institute of Defence and Strategic Studies, Nanyang Technological University, 2003), 49. 


\section{Sejarah Berdirinya Negara Islam Indonesia (NII)}

Negara Islam Indonesia (NII) yang kemunculannya oleh berbagai pihak dituding sebagai akibat dari merasa sakit hatinya kalangan Islam, dan bersifat spontanitas, lahir pada saat terjadi vacuum of power di Republik Indonesia (RI). Sejak tahun 1926, telah berkumpul para ulama di Arab dari berbagai belahan dunia, termasuk Haji Oemar Said (HOS) Tjokroaminoto, guna membahas rekonstruksi khilafah Islam yang runtuh pada tahun 1924.

Sayangnya, musyawarah para ulama tersebut tidak membuahkan hasil dan tidak ada tindak lanjutnya. Sekarmadji Maridjan Kartosoewirjo yang merupakan orang kepercayaan Tjokroaminto kemudian berinisiatiaf menindaklanjuti usaha rekonstruksi khilafah Islam dengan menyusun brosur sikap hijrah berdasarkan keputusan kongres Partai Syarekat Islam Indonesia (PSII) 1936. ${ }^{4}$ Kemudian pada 24 April 1940, Kartosoewiryo bersama para ulama mendirikan di Malangbong Institut Ṣuffah yang merupakan suatu laboratorium pendidikan tempat mendidik kader-kader mujahid seperti di zaman Nabi Muhammad saw. Institut Șuffah yang didirikan telah melahirkan pembelapembela Islam dengan ilmu Islam yang sempurna dan keimanan yang teguh. ${ }^{5}$

Alumnus Șuffah kemudian menjadi cikal bakal Laskar HizbullāhSabīillāah. Laskar Hizbullāh-Sabīlillāh tidak diizinkan ikut hjrah ke Yogyakarta mengikuti langkah yang diambil tentara Republik Indonesia, sebagai akibat dari sikap keras tokoh-tokoh politiknya. Laskar inilah yang pada akhirnya menjadi Tentara Islam Indonesia (TII). Hingga pada tanggal 10 Februari 1948, diadakan sebuah konferensi di Cisayong yang menghasilkan keputusan membentuk Majelis Islam dan mengangkat Kartosoewirjo sebagai Panglima Tinggi Darul Islam/Tentara Islam Indonesia (DI/TII). ${ }^{6}$ Pada tanggal 7 Agustus 1945 Kartosoewiryo secara resmi memproklamirkan berdirinya Negara Islam Indonesia (NII) yang dalam sejarah awal berdirinya dikenal dengan nama Darul Islam (DI) dengan pasukan pejuang yang dinamakan Tentara Islam Indonesia (TII). ${ }^{7}$ Semenjak pertengahan tahun 1949 Tentara Republik Indonesia

${ }^{4}$ Keterkaitan antara gerakan Pan Islamisme dengan ide pembentukan negara agama oleh Kartosuwiryo secara baik telah dijelaskan oleh Chiara Formichi, "Pan-Islam and Relegious Nationalism: the Case of Kartosuwiryo and Negara Islam Indonesia", Indonesia, The Journal is Published by Cornell University's Southeast Asia Program, Vol 90 (Oktober 2010), 125-146.

${ }^{5}$ Lihat Suroso Abdul Salam, NII dalam Timbangan Aqidah (Jakarta: Pustaka alKautsar, 2000), 39-40.

6 Mahatma Hadi, dkk. Negara Islam Indonesia; Fakta Sejarah dan Perkembangannya (Jakarta: FH Uinversitas Indonesia, 2005), 4.

7 Lihat Jeff Lee, "The Failure of Political Islam in Indonesia: A Historical Narrative, Stanford Journal of East Asian Affairs, Vol, 4. Number 1, (Winter 2004), 90. 
berhadapan secara langsung sehingga terjadi kontak senjata dengan DI/TII dibawah pimpinan Kartosoewirjo. ${ }^{8}$ Namun kemudian Kartosoewirjo ditangkap pada 4 Juni 1962 di tempat persembunyiannya di Gunung Sangkar dan Gunung Geber dalam keadaan sakit yang cukup serius. Beliau kemudian ditandu oleh tentara Republik Indonesia karena sudah tidak mampu berjalan, yang saat itu beliau berusia 59 tahun. Kemudian atas keputusan majelis hakim pada saat itu dinyatakan bersalah dengan tuduhan makar dan dihukum dengan hukuman mati. S.M. Kartosoewirjo kemudian dieksekusi mati pada bulan September 1962 di sebuah pulau di teluk Jakarta. Beliau meninggalkan seorang istri Siti Dewi Kulsum dan 12 orang anak.

Pasca kepemimpinan S.M. Kartosoewirjo, NII kemudian dipegang oleh Kahar Muzakkar (1962 - 1965), kemudian oleh Agus Abdullah (1965 - 1970) dan Teungku Daud Beureuh (1970 - 1980). Pasca kepemimpinan ini, NII terpecah menjadi beberapa faksi, karena terjadi perselisihan paham dan pendapat tentang siapa yang lebih berhak menggantikan posisi Imam NII: ada kubu Mujahidin dalam wadah Fillāh di bawah komando Djaja Sujadi, dan Mujahidin dalam wadah Sabilillāh di bawah komando Adah Djaelani Tirtapradja. Kemudian kubu Sabīillāh ini pecah lagi menjadi beberapa faksi, yaitu Faksi Abdullah Sungkar, ${ }^{9}$ yang meliputi wilayah Jawa Tengah dan Yogyakarta, faksi Atjeng Kurnia yang meliputi wilayah Bogor, Serang, Purwakarta, dan Subang, faksi Ajengan Masduli yang meliputi wilayah Puwokerto, Subang, Cianjur, Jakarta dan Lampung, faksi Abdul Fatah Wiranagapati yang meliputi wilayah Garut, Bandung, Surabaya dan Kalimantan, dan faksi Gaos Taufik yang meliputi wilayah Pulau Sumatera.

Perpecahan terus melanda para tokoh dan anggota NII ini. Hal itu terjadi pada tahun 1990-an saat pelimpahan dari Adah Djaelani kepada Abu Toto yang menurut anggota lainnya dianggap tidak pernah terdaftar sebagai anggota DI. Bahkan, dia dianggap banyak memutarbalikkan sejarah perjuangan jihad

${ }^{8}$ Kartosuwiryo membagi struktur komando ke dalam beberapa bentuk; Pertama, Komandemen Perang Seluruh Indonesia (KPSI). Kedua, Komandemen Perang Wilayah Besar (KPWB). Ketiga, Komandemen Perang Wilayah (KW) meliputi, KW 1 Priangan Utara, KW 2 Jawa Tengah, KW 3 Jawa Timur, KW 4 Sulawesi, KW 5 Kalimantan, KW 6 Aceh, KW 7 Priangan Selatan. Namun pasca ditangkapnya Abu Daud yang menggantikan Kartosuwiryo NII pecah lagi dengan ditambahnya KW 8 Lampung dan KW 9 Jakarta Raya yang meliputi Bekasi, Jakarta,Tengerang dan Banten. Lihat Sukanto, "Membedah Gerakan Negara Islam Indonesia Komandemen Wilayah IX", Seminar Bahaya Laten NII KW IX Masuk Kampus di Universitas Sahid, 5.

9 Abdullah Sungkar juga kemudian diketahui memiliki hubungan sangat erat dengan $\mathrm{Abu}$ Bakar Ba'asyir pendiri Jama'ah Islamiyah yang juga sama-sama memperjuangkan berdirinya negara Islam. Lihat Ahmad Fauzi Abdul Hamid, Repoliticisation of Islam in Southeast Asia (Singapore: Bertelsmann Stiftung, 2009), 7. 
menegakkan Negara Islam, menyelewengkan pemikiran politik kenegaraan yang telah dirumuskan Imam Kartosoewirjo. Yang paling esensi adalah terjadinya penyimpangan dari manhaj nubuwwah dalam merealisasikan pembentukan mulkiyah Allah. ${ }^{10}$ Namun demikian, Abu Toto terus mengembangkan pengaruh dan kekuasannya bahkan hingga di luar batas-batas wilayahnya yang sekarang disebut NII KW. IX dan berpusat di Pesantren al Zaytun, Mekar Jaya, Haur Geulis, Indramayu Jawa Barat, dan kemudian pimpinannya dikenal dengan nama Panji Gumilang. ${ }^{11}$ Maka tulisan ini pada initinya lebih difokuskan untuk menyorot ajaran dan paham keagamaan NII KW IX pimpinan Panji Gumilang, dikarenakan eksistensi dan gerakan mereka yang masih eksis dan terlihat sampai saat ini. Dalam konteks tulisan ini salah satu kitab utama yang menjadi sorotan dan fokus kajian adalah kandungan kitab pokok ajaran NII KW IX berjudul al-Islam dan Buku Pedoman Tazkiyah. ${ }^{12}$ Kedua kitab ini adalah rujukan utama bagi pengikut NII KW IX dan merupakan buku pegangan utama dalam membangun konsepsi tauhid mereka. Buku ini, menurut penulis ditulis sendiri oleh Abu Toto atau Syaikh Panji Gumilang pemimpin gerakan NII KW IX Indramayu Jawa Barat, sekalipun pada kulitnya tidak dicantumkan nama pengarang dan yang disebutkan hanya NII KW IX.

\section{Doktrin dan Ajaran Negara Islam Indonesia (NII)}

Secara garis besar doktrin dan ajaran NII dikategorikan kepada dua hal; pertama terkait dengan akidah dan kedua terkait dengan syari'ah dan ibadah. Doktrin dan ajaran yang terakit dengan akidah meliputi konsepsi din al-Isläm, konsep tauhid dan hubungan Islam dan negara serta langkah-langkah mewujudkan negara Islam meliputi bai'at, hijrah dan jihad. Sementara doktrin

${ }^{10}$ Sidik Budiyanto, Mewaspadai NII Zaytun di Kampus Kita (Jakarta: Kalamnet Publishing, 2006), 7-8.

11 Melalui yayasan berupa pesanteren al-Zaytun inilah Pani Gumilang secara konsisten merekrut anggota demi mewujudkan ide mendirikan negara Islam. Lihat Martin van Bruinessen, "Divergent Paths From Gontor: Muslim Educational Reform and the Travails of Pluralsm in Indonesia" dalam Pak Karel, Pesantren, and Pluralism. Jurnal Penelitian Kependidikan, Tahun 16, Nomor 1, (Juni 2006), 196. Terkait dengan peranan pesantren secara lebih umum sebagai tempat dicetuskan dan diperjuangakan sebuah ideologi juga telas dijelaskan dalam Farish A. Noor, Yoginder Sikand \& Martin van Bruinessen (eds), The Madrasa in Asia: Political Activism and Transnational Linkages (Amsterdam: Amsterdan University Press, 2007).

${ }^{12}$ Berhubung kedua kitab ini tidak pernah dipublikasikan, bersifat tertutup dan hanya dibaca di kalangan internal tokoh dan pengikut NII KW IX saja, maka penulis sendiri tidak berkesempatan membacanya secara langsung. Doktrin ajaran NII KW IX yang penulis sorot dalam tulisan berdasarkan sumber kedua yaitu berdasarkan penelitian Asep Zaenal Ausep dalam penelitian disertasinya yang memang berkesempatan membaca langsung kedua kitab ini. 
dan ajaran yang terkait syari'ah dan ibadah meliputi konsepsi ibadah seperti shalat, puasa, haji, zakat, sadaqah, qirad dan fà'i. Selanjutnya syari'at pernikahan terkait wali biologi dan wali ideologi dan lain-lain. ${ }^{13}$

Terkait konsepsi din al-Islām menurut kelompok NII bahwa yang dimaksud dengan kata ini bukanlah agama Islam dalam pengertian religion seperti yang dipahami oleh mayoritas umat Islam. Akan tetapi, yang dimaksud dengan din al-Isläm adalah tata cara hidup yang dilandasi oleh ajaran Islam. Konsekwensi dari pemahaman itu adalah bahwa untuk terwujudnya Islam sebagai tata cara hidup dalam tubuh umat Islam maka jalan satu-satunya adalah dengan mendirikan negara Islam. Hanya dengan kekuatan potiklah Islam sebagai norma bisa diterapkan dalam kehidupan secara total. ${ }^{14}$

Adapun masalah tauhid yang terkait hubungan Islam dan negara menurut NII bahwa pondasi kehidupan seorang individu sebagai seorang muslim adalah tauhid. Hanya tauhid yang benarlah yang menjadikan seorang muslim sejati. Sedangkan tauhid itu dalam pandangan kelompok NII dibagi tiga; tauhid

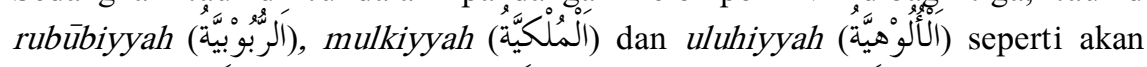
dijelaskan padá bagian berikutnya dálam makalah ini. Implémentasi dari ketiga jenis tauhid inilah yang memunculkan paham wajibnya mendirikan negara Islam. $^{15}$

Adapun langkah-langkah menegakan negara Islam meliputi bai'at, hijrah dan jihad. Bai'at diperlukan karena untuk membangun sebuah negara diperlukan jama'ah dan kelompok besar. Jama'ah ini hanya bisa lahir dari proses bai'at. Bai'at dalam konsep NII berarti seseorang telah menjual dirinya untuk menegakan aturan Allah, sesuai dengan arti kata bai'at sendiri yang berasal dari kata baya'a (بَ) yang berarti menjual. ${ }^{16}$ Pemahaman seperti inilah yang kemudian melahirkan sikap berkorban yang tanpa batas dalam diri para pengikut NII, baik berupa materi maupun non materi. ${ }^{17}$ Adapun hijrah baru bisa

${ }^{13}$ Sebagaimana dijelaskan semua konsepsi tentang doktrin dan ajaran ini dijelaskan dalam kitab rujukan utama NII KW IX seperti buku al-Islam dan buku Pedoman Tazkiyah. Namun, kedua buku ini masih tertutup dan tidak pernah dicetak secara resmi untuk dipublikasikan. Buku ini merupakan bagian dari doktrin NII yang harus disembunyikan dan hanya tokoh dan pengikut NII saja yang bisa membaca dan memiliki akses terhadapnya.

${ }_{15}^{14}$ NII KW IX, al-Islam, 9.

15 Asep Zaenal Ausep, "Demokrasi dan Musyawarah Dalam Pandangan Darul Arqam, NII dan Hizbut Tahrir Indonesia", Jurnal Sosioteknologi Edisi 17 Tahun 8, Agustus (2009), 609.

${ }^{16}$ Pengertian ini dipahami dari firman Allah dalam surat al-Taubah [9]: 111 dan alȘaf [61]: 10 .

${ }^{17}$ Kesesatan bai'at ini telah dijelaskan oleh Abdul Halim bin Amir Abdat, Risalah Bid'ah (Jakarta: Pustaka Abdullah, 2010), 312-313. 
dilakukan setelah proses bai'at yang meliputi hijrah jasmani dan rohani. Pemahaman hijrah ini didasarkan pemahaman terhadap surat al-Balad [90]: 10 di mana Allah menyebutkan kata al-Najdayn (النَّجْدَيْنْ) yang ditunjukkan Allah kepada manusia yang dalam pemahaman kelompok NII kata itu diartikan dua negeri; negeri bathil dan negeri haq. Negeri bathil adalah negara Republik Indonesia yang didirikan tanggal 17 Agustus 1945 oleh Soekarno dan Hatta dengan nama Negara Kesatuan Republik Indonesia (NKRI), sedangkan negeri yang haq (benar) adalah negara yang didirikan oleh Kartosoewirjo, 7 Agustus 1949 dengan nama Negara Karunia Allah-Negara Islam Indonesia (NKA-NII). Maka seorang muslim yang sudah berbai'at wajib hijrah baik jasmani maupun rohani ke dalam NII tersebut dan menunggalkan NKRI. Konsekwensi dari hijrah bahwa seorang muslim haruslah berjihad baik dengan harta maupun dengan nyawanya demi tegakkan negara Islam. ${ }^{18}$

Sementara doktrin yang terkait dengan syari'ah dan ibadah seperti shalat, puasa, haji, zakat dan sebagainya, kelompok NII juga memiliki paham yang berbeda dengan pemahaman mayoritas umat Islam. Shalat misalnya, kelompok NII tidak lagi memahamai shalat dalam arti ritual aqim al-salăh (أَقِم

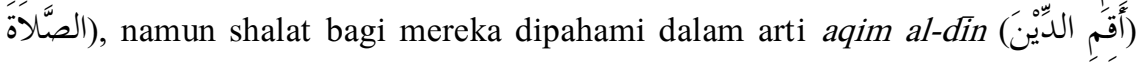
yaitu mendirikan agama. Tidaklah ada arti shalat seseorang walaupun ribúan rakaat, jika dia tidak berupaya untuk menegakan negara Islam. Mereka lebih memahami shalat dalam konteks subtansi dan bukan formalitas. Jika seseorang misalnya sudah tercegah dari perbutan keji dan munkar maka dia tidak perlu lagi shalat ritual. Di sisi lain, seperti disebutkan Allah swt. bahwa shalat itu supaya ingat pada-Ku, ${ }^{19}$ maka shalat bisa saja dan boleh diwakili dengan hanya berzikir, berdo'a, tilāwah al-Qur'ān (تلاوَّة القرَّآن) dan sejenisnya. Merekapun membagi shalat itu ke dalam dua període sesuá dengan periode dakwah dan upaya nabi Muhammad saw. mendirikan negara Islam; yaitu peride Makkah dan Madinah. Pada periode Makkah usaha Nabi Muhammad saw. lebih berorientasi aqidah bukan ibadah, karena itu shalat belum dikerjakan dalam periode Makkah. Barulah setelah periode Madinah ketika negara Islam Madinah sudah berdiri ibadah shalat secara utuh dikerjakan. Kelompok NII memahami bahwa kondisi sekarang umat Islam Indonesia masih hidup dalam periode Makkah karena negara Islam belum berdiri, maka pelaksanaan shalat dalam bentuk ritual belum terlalu penting dan mendesak untuk dikerjakan. ${ }^{20}$ 
Sama halnya dengan shalat, bagi pengikut NII puasa juga belum diwajibkan sebelum negara Islam berdiri, karena dalam sejarah syari'at, puasa baru dikerjakan tahun kedua setelah terbentuknya negara Islam di Madinah. Begitu juga dengan ibadah Haji yang baru wajib jika sudah diundangkan oleh negara Islam yang sah. Bukankah nabi Muhammad baru berhaji setelah sepuluh tahun berdirinya negara Madinah. ${ }^{21}$

Namun, ini berbeda halnya dengan zakat dan shadaqah yang sudah mereka wajibkan semenjak bai' at dilakukan. ${ }^{22}$ Hal itu dipahami dari arti bai' at

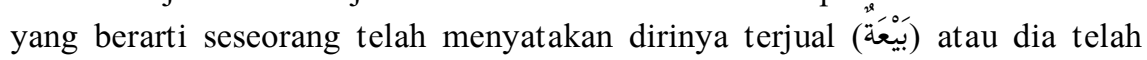
menjual diri secara total untuk berupaya menegakkan aturan Allah. Lebih lanjut dijelaskan bahwa hal itu telah ditunjukkan oleh para sahabat yang mulai semenjak periode Makkah seperti yang dilakukan oleh Khadijah, Abu Bakar, Usman bin Affan, Abdurrahman bin Auf dan sebagainya. Mereka berpendapat bahwa materi adalah penopang utama berjalannya aktifitas dakwah dalam rangka mewujudkan berdirinya negara Islam, sehingga, pengorbanan materi dari para pengikut secara besar-besaran sangat dibutuhkan apakah dalam bentuk zakat, shadaqah maupun infaq. ${ }_{\dot{0}}^{23}$

Sedangkan qiraḍ (آلْرْضْ) berarti meminjamkan Allah swt sejumlah harta dengan mengharap pengemb́alian berupa pahala yang berlipat ganda dari Allah. $^{24}$ Anggota NII didorong untuk bisa meminjamkan hartanya sebesar mungkin demi mendapatkan pahala yang berlipat ganda. Dogma inilah yang kemudian sukses menjadikan dakwah NII begitu cepat dengan dukungan finasial anggotanya yang tak terbatas. Bahkan demi melaksankan qirad ini tidak sedikit anggotanya yang melakukan pencurian harta orang lain bahkan harta keluarga mereka sendiri demi memenuhi tuntutan qiraḍ. Bagi mereka, melakukan pencurian itu terhadap harta yang bukan NII adalah halal, karena mereka dianggap kafir. ${ }^{25}$

${ }^{21}$ Lihat NII KW IX, al-Islam, 30-31.

${ }^{22}$ Inilah salah satu wujud ketidakkonsistenan pemahaman kelompok NII yang cenderung mengambil kesimpulan dan hukum yang sesuai dengan selera dan keinginan mereka. Sebab, jika berkaca pada sejarah penetapan syari'at justru zakat atau shadaqahlah syari'at yang paling terakhir diperintahkan Allah. Ia dilaksanakan Nabi Muhammad saw. setelah perintah shalat, haji dan puasa.

${ }^{23}$ Lihat lebih lanjut Tim Peneliti Indonesian Institute for Society Empowerment (INSEP), Al-Zaytun The Untold Stories; Investigasi terhadap Pesantren Paling Kontroversial di Indonesia (Jakarta: Pustaka Alvabet, 2011), 132.

${ }^{24} \mathrm{Hal}$ ini dipahami dari firman Allah surat al-Hadid [57]: 11, al-Baqarah [2]: 245, al-Ma'idah [5]: 12 dan al-Taghabun [64]: 17.

${ }^{25}$ Lihat Asep Zainal Ausop, Ajaran dan Gerakan NII KW IX\& Ma'had al-Zaytun, 201. Pernyataan ini ditulis berdasarkan wawancara penulis dengan anggota NII KW IX. 
Terkait masalah pernikahan, NII berpendapat bahwa anggota NII hanya boleh dan sah menikah dengan sesama pengikut NII. Mereka diharamkan menikah dengan orang di luar pengikut NII kecuali setelah berbai'at menjadi pengikut NII terlebih dahulu. Alasan mereka adalah bahwa seorang laki-laki muslim hanya halal menikah dengan perempuan muslim begitu juga sebaliknya. ${ }^{26}$ Sedangkan orang orang yang di luar NII masih dianggap kafir atau musyrik, karena mereka belum beraqidah secara benar seperti akidahnya kelompok NII ini. Dampaknya adalah bahwa seorang perempuan yang menjadi anggota NII dan hendak menikah, sedangkan bapaknya bukan pengikut NII maka bapaknya tidak boleh menjadi wali pernikahannya. Andaikata perempuan tadi telah dinikahkan oleh bapaknya secara sah dan tercatat pada KUA, maka pernikahan tetap harus diulang dalam internal NII dengan wali ideologi (imamnya NII) barulah sah pernikahan dan hubungan yang mereka jalani. Kelompok NII tidak mengakui sahnya pernikahan sekalipun tercatat di KUA karena KUA juga merupakan representasi pemerintahan yang musyrik. ${ }^{27}$

\section{Pemahaman Shajarah Tayyibah dan Ide Negara Islam}

Seperti disebutkan di awal, bahwa ide yang melatarbelakangi NII membentuk negara Islam adalah pemahaman mereka terhadap shajarah tayyibah seperti disebutkan dalam surat Ibrahim [14]: 24-25:

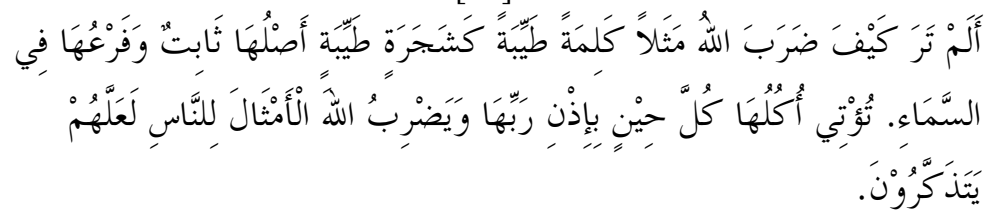

Artinya: Tidakkah kamu perhatikan bagaimana Allah telah membuat perumpamaan kalimat yang baik seperti pohon yang baik, akarnya teguh dan cabangnya (menjulang) ke langit. pohon itu memberikan buahnya pada Setiap musim dengan seizin Tuhannya. Allah membuat perumpamaan-perumpamaan itu untuk manusia supaya mereka selalu ingat.

Dalam pemahaman kelompok NII bahwa ini adalah tamsilan dari sebuah tatanan masyarakat yang ideal. Pohon yang baik itu diibaratkan sebuah negara yang memiliki tiga ciri penting; أَصْلُهَا ثَابت

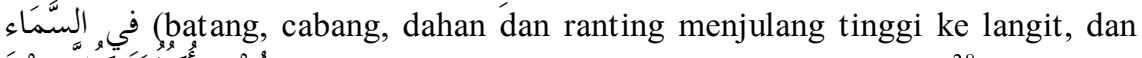

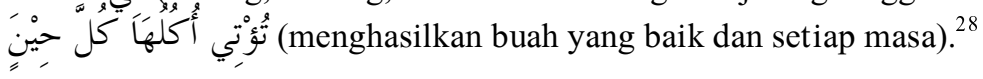

\footnotetext{
${ }^{26}$ Q.S al-Baqarah [2]: 221.

${ }^{27}$ Penjelasan lebih rinci lihat Asep Zainal Ausop, Ajaran dan Gerakan NII,179-206

${ }^{28}$ NII KW IX, Buku Pedoman Tazkiyah, 29.
} 
Bila tamsilan itu diproyeksikan terhadap sebuah tatanan negara, akarnya yang kokoh itu adalah undang-undang yang kokoh dan tidak akan pernah berubah dan itulah al-Qur'an. Batang, cabang, dahan dan ranting yang menjulang tinggi itu adalah negara yang berlandaskan Islam sebagai agama yang tidak ada melebihi ketinggiannya. Sementara buahnya yang baik dan terus menerus itulah masyarakat yang dihasilkan oleh negara Islam yang berlandaskan al-Qur'an tersebut. ${ }^{29}$

Menurut pemahaman kelompok NII, adalah sesuatu yang tidak mungkin dan sangat mustahil bila sebuah pohon memiliki akar yang busuk dan rapuh bisa menghasilkan buah yang baik. Bahkan tidak mungkin juga bila akarnya busuk bisa mempertahankan batangnya tetap berdiri kokoh. Begitu juga, adalah tidak mungkin bila pohon berakar semangka bisa menghasilkan buah mangga. Maka, pemikiran yang rasional adalah bila pohon mangga dengan akar mangga pastilah akan menghasilkan buah mangga. Demikianlah sebuah negara, yakni bila akarnya (undang-undangnya) Islam, batangnya (negaranya) Islam, pastilah buahnya (umatnya) Islam. ${ }^{30}$

Dari sinilah bermula ide pembentukan negara Islam oleh kelompok NII. Dalam pandangan mereka, negara Indonesia yang didirikan tanggal 17 Agustus 1945 adalah negara kafir karena menganut sistem republik yang diambil dari sistem negara kafir dan berdasarkan Pancasila bukan al-Qur'an. Oleh karena itu, Indonesia tidak bisa diubah secara parsial, tetapi harus diubah secara total dan revolusioner dari bentuk "Negara kafir Indonesia" menjadi format negara "Negara Islam Indonesia". Pandangan ini jugalah yang kemudian melahirkan ide jihad dan konsep revolusi Islam NII. ${ }^{31}$

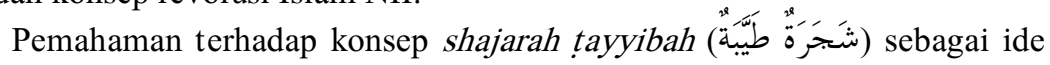
kewajiban dibangunnya negara Islam juga didasarkan kepada pemahaman tentang konsep trilogi akidah mereka yang mereka sebut dengan aqidah

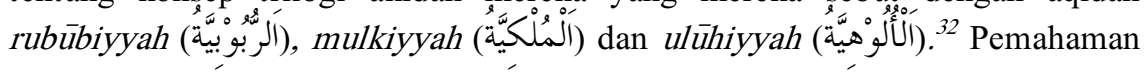
ini berasal dari tafsiran mereka térhadap munasabah surat al-Fātihah (surat pertama) dengan surat al-Nās (surat terakhir). ${ }^{33}$

Menurut pemahaman mereka, antara kedua surat ini memiliki hubungan yang sangat erat baik secara redaksional maupun pesan dan isi. Surat al-Fātihah

${ }^{29}$ Asep Zainal Ausop, Ajaran dan Gerakan NII, 132

${ }^{30}$ Asep Zainal Ausop, Ajaran dan Gerakan NII, 132. Konsep ajaran ini juga pernah dipublikasikan dalam Majalah al-Zaytun no.11 (2000), 31.

${ }^{31}$ Asep Zaenal Ausep, "Demokrasi dan Musyawarah Dalam Pandangan Darul Arqam, NII dan Hizbut Tahrir Indonesia”, 611.

${ }^{32}$ NII KW IX, al-Islam, 49.

${ }^{33}$ NII KW IX, Buku Pedoman Tazkiyah, 29. 
dianggap sebagai pendahuluan yang menggambarkan keseluruhan isi al-Qur'an sedangkan surat al-Nās dianggap kesimpulan yang juga merupakan sari dari semua uraian al-Qur'an. Ternyata menurut pemahaman mereka bahwa kedua surat ini sama-sama menekankan pentingnya trilogi tauhid bagi umat Islam; rubūbiyyah, mulkiyyah dan ulühiyyah. ${ }^{34}$ Untuk jelasnya bisa dilihat tabel berikut: ${ }^{35}$

\begin{tabular}{|c|c|c|c|}
\hline No & al-Fātiḥah & al-Nās & Munasabah \\
\hline 1 & آلْحَمْنُ لَلَّه رَبِِّ الْعَالَمَيْنَ & قُلْ أَعُوْْذُ برَبِبِ النَّاس & $\begin{array}{l}\text { Keduanya melahirkan } \\
\text { tauhid rubübiyyah }\end{array}$ \\
\hline 2 & مَالكِ يَوْمَ الدِّينَ & مَلكِ النَّاس & $\begin{array}{l}\text { Keduanya melahirkan } \\
\text { tauhid mulkiyyah }\end{array}$ \\
\hline 3 & رإَّاَكَ نَعْبُدُ وَإِيَّاكَ نَسْتَعْيْنَ & إِلَهِ النَّاس & $\begin{array}{l}\text { Keduanya melahirkan } \\
\text { tauhid ulühiyyah }\end{array}$ \\
\hline
\end{tabular}

Tauhid rubūbiyyah berarti bahwa hanya Allah sajalah satu-satunya Tuhan yang mengatur alam semesta termasuk manusia. Tauhid mulkiyyah berarti bahwa hanya Allah sajalah satu-satunya Raja di alam ini termasuk Raja manusia, dan Tauhid ulühiyah berarti hanya Allah sajalah satu-satunya Tuhan yang berhak disembah. ${ }^{36}$

Hubungan ketiga jenis tauhid ini dengan konsep shajarah tayyibah

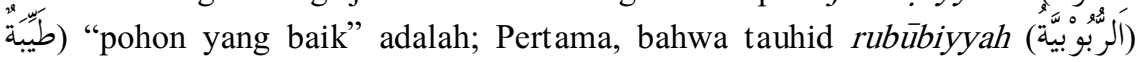
berarti manusia harus menjadikan Allah sebagai satu-satu sumber pengatur, sementara aturan Allah itu terdapat di dalam al-Qur'ān. Sedangkan konsep shajarah tayyibah pertama adalah akarnya harus kokoh dan akar itu adalah dasar hukum sebuh negara. Oleh karena itu manusia harus menegakkan hukum Allah dalam hal ini adalah al-Qur'ān bukannya Pancasila. Jika tidak maka berarti manusia belum bertauhid secara rubübiyyah dan tetap kafir sebelum menjadikan al-Qur'ān sebagai dasar negara yaitu akar dari pohon yang baik itu.

Kedua, tauhid mulkiyyah (آلَمْنْكََّّة) berarti manusia mengakui dengan sungguh-sungguh bahwa hanya Alláh yang menjadi Raja di alam ini. Oleh karena itu manusia harus mendirikan kerjaan (negara) Allah di muka bumi ini, bukannya NKRI. Negara Allah yang dimaksud adalah negara Islam yang

${ }^{34}$ Inilah perbedaan tauhid NII dengan kelompok teologi Islam lainnya yang hanya memiliki dua jenis tauhid; yaitu rubübiyyah dan ulühiyyah.

${ }^{35}$ Tabel dibuat oleh Asep Zaenal Ausep, "Demokrasi dan Musyawarah Dalam Pandangan Darul Arqam, NII dan Hizbut Tahrir Indonesia”,608.

${ }^{36}$ Asep Zainal Ausop, Ajaran dan Gerakan NII, 121 
didasarkan hukum-hukum Allah, sehingga, selama kerajaan (negara) Islam belum ditegakkan maka selama itu pula manusia belum bertauhid secara mulkiyyah. Itu berarti bahwa batang pohon itu bukan pohon yang baik karena tidak menjulang ke langit.

Ketiga, tauhid ulūhiyyah (آنألوْهيَّة) berarti bahwa manusia mengesakan Allah dalam penyembahan. Bahwá umat Islam yang hidup di negara Islam bukan umat yang beragama dan bersifat gado-gado. Umat Islam yang ideal adalah satu warna, satu format dengan sistem dan tata cara peribadatan yang sama. Itu baru bisa terwujud jika negaranya Islam dan dasarnya al-Qur'ān. Maka ibarat pohon yang baik tadi, manusia atau umat Islam yang Islami dan hanya satu warna sebagai wujud buah bisa lahir jika negaranya Islam sebagai wujud batang yang tinggi dan dasarnya al-Qur'ān sebagai wujud dari akar yang kokoh. ${ }^{37}$

\section{Respon Terhadap Pemahaman Shajarah Tayyibah}

Metode penafsiran al-Qur'an yang dilakukan oleh NII ini terhadap surat Ibrahim ayat 24-25 tersebut termasuk menggunakan tafsir bi al-ra'yi al-siyass $\bar{i}$

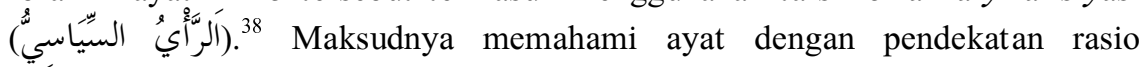
bertendensi politis. Dikatakan demikian karena penafsiran yang dilakukan oleh kelompok NII ini lebih kepada upaya pembenaran dan legitimasi untuk menyokong dan mengokohkan ide akan kewajiban mendirikan negara Islam. ${ }^{39}$

Dalam kitab-kitab tafsir tidak pernah dijumpai ada penafsiran mufassir terkait ayat-ayat yang ditafsirkan oleh kelompok NII ini dengan penafsiran seperti yang mereka lakukan. Terkait surat Ibrahim [14]: 24-25, dari sekian banyak mufasir dengan ragam metode dan pendekatan yang digunakan tidak ada yang menyimpulkan demikian. Apakah dalam kitab-kitab tafsir dengan,

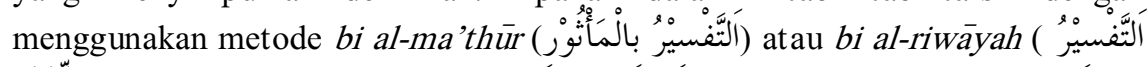
بالرِّوَايَة ál-Suyūṭ̂i dan sebagainya ataupun dalam kitab-kitab tafsir dengan menggunakan

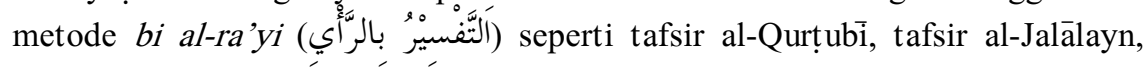
tafsir al-Bayḍawi hingga yang dianggap tafsir paling rasional sekalipun yaitu tafsir Zamakhshari.

37 Asep Zaenal Ausep, "Demokrasi dan Musyawarah Dalam Pandangan Darul Arqam, NII dan Hizbut Tahrir Indonesia",608-609.

${ }^{38}$ Asep Zainal Ausop, Ajaran dan Gerakan NII, 133

39 Bantahan ini bahkan kesimpulan hingga sampai pada tingkat penyesatan dan pengkafiran sebanarnya sudah dituduhkan kepada kelompok NII dengan pemahaman yang keliru ini oleh Hartono Ahmad Jaiz, Aliran dan Paham Sesat di Indonesia (Jakarta: Pustaka al-Kautsar, 2002), 45-50. 
Al-Ṭabari misalnya, menafsirkan surat Ibrāhim [14]: 24-25 sebagai bentuk perumpamaan tentang iman yang benar dan kokoh. Kata shajarah

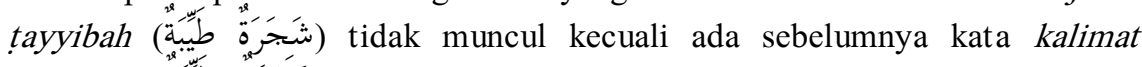
tayyibah (كلمَة طيبّة (كية) dan dan yang dimaksud dengannya adalah dua kalimat syahadat. Sedangḱan seperti pohon yang baik adalah seorang mukmin yang telah mengucapkan kalimat syahadat itu dengan benar. Akarnya yang kokoh adalah kalimat là ilaha illalllāh (لاً إلََهَ إنَّا اللَّ) itu menghujam kokoh di hati orang mukmin. Cabangnya menjulang ke lángit artinya amalnya yang didasari akidah yang kokoh begitu tinggi dan terhormat. Begitulah riwayat yang diterima dan diriwayatkan dari ibn Abbas. Sedangkan riwayat dari Abdullāh ibn Abi Ja'far menjelaskan bahwa shajarah tayyibah (شَجَرَة طَيِّة iman. Akarnya yang kokoh itu adalah keikhlasan seorang mukmin, cabangnya yang menjulang ke langit adalah rasa takut kepada Allah. ${ }^{40}$

Di sini lain Ibn 'Abbas dari riwayat Muhammad ibn Sa'ad menjelaskan bahwa pohon yang baik itu adalah seorang mukmin, di mana dia berbuat yang baik dan kokoh di bumi sehingga amal kebaikannya itu terangkat ke langit dengan derajat yang sangat tinggi sekalipun dia masih berada di bumi. Sementara Abu Ahmad meriwayatkan bahwa yang dimaksud pohon yang baik itu perumpamaan seorang mukmin yang senantiasa keluar dari dirinya perkataan dan perbuatan yang baik dan amal shalih yang terus naik ke langit, sehingga namanya begitu terkenal di langit di kalangan para malaikat. ${ }^{41}$

Ibn Kathïr misalnya menjelaskan ayat tersebut dengan mengutip apa yang disampaikan Ibn Abbas bahwa yang dimaksud kalimah tayyibah adalah shahādat an lā ilaha illā Allāh dengan mengumpamakannya dengan seorang mukmin, yaitu ibarat sebatang pohon yang baik. Akarnya yang kokoh berarti bahwa kalimat là ilaha illā Allāh itu menghujam kokoh di hati seorang mukmin. Batang dan rantingnya menjulang ke langit berarti dengan kalimat là ilaha illà Allah itu diangkatlah semua amal mukmin itu menuju langit. Artinya semua amal yang landasi iman yang benar, tauhid yang kokoh serta keikhlasan akan diangkat ke langit dengan penuh kemulian. ${ }^{42}$

Al-Baydawi menjelaskan shajarah tayyibah dalam ayat di atas dengan menyebutkannya sebagai pohon korma yang merupakan tashbih terhadap

\footnotetext{
${ }^{40}$ Lihat penjelasan lebih rinci dalam Abu Ja'far Muhammad Jarīr al-Ṭabari, Jāmi', al-Bayān 'an Ta'wīl Āy al-Qur'ān, Juz 13 (al-Qāhirah: Markaz al-Buhūth wa al-Dirāsat al-'Arabiyah wa al-Islāmiyah, 2001), 634-635.

${ }^{41}$ Abu Ja'far Muhammad Jarīr al-Ṭabari, Jāmi' al-Bayān 'an Ta'wīl Āy al-Qur'ān, Juz 13, 636.

${ }^{42}$ Abu al-Fidā' Ismā'îl ibn Umar ibn Kathīr al-Qurashī al-Dimashqī, Tafs̄̄r alQur'ān al- 'Aẓīm, Juz 4 (al-Riyāḍ: Dār al-Ṭibbiyah li al-Nashr wa al-Tawzī', 1999), 491.
} 
seorang mukmin sejati, di mana korma adalah pohon yang akarnya sangat kuat sehingga bisa bertahan di tengah padang pasir dengan terpaan angin dan badai yang sangat kencang. Korma juga dikenal sebagai pohon yang batangnya menjulang tinggi, dan juga menghasilkan buah dengan beragam pilihan seperi basah, kering dan sebagainya. Begitu pulalah gambaran seorang mukmin yang sejati, aqidahnya kuat, amalnya baik dan mulia serta akhlaknya membuat semua orang merasa aman dan bahagia. ${ }^{43}$

Adapun al-Zamakhsyari menjelaskan bahwa yang dimaksud dengan al-

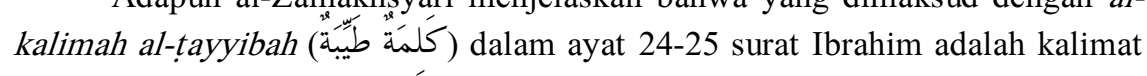
tauhid, yang mencakup semúa kata-kata yang baik seperti al-tasbịh, al-tahmid,

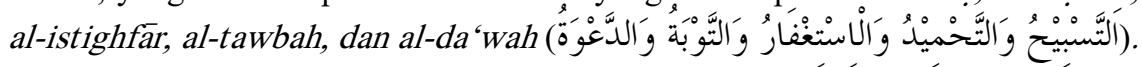
Ayat ini mengumpamakan seorang mukmin yang keiḿánannýa kokoh akan menjadikannya memiliki pribadi dan ketinggian amal, kehormatan diri serta melahirkan akhlak terpuji setiap saat. Keadaannya sama seperti pohon yang baik dengan akar yang kokoh akan memiliki batang yang kokoh dan tingggi menjulang dan memberikan buah dengan buah yang baik setiap waktu, seperti pohon korma, pohon tin, pohon delima dan seterusnya. ${ }^{44}$

Selanjutnya Tabātabā'ì seorang mufassir shi'ah yang dikenal dengan corak penafsiran al-Qur'an dengan al-Qur'an juga tidak menafsirkan ayat tersebut dalam konteks kekuasaan dan politik atau kewajiban mendirikan

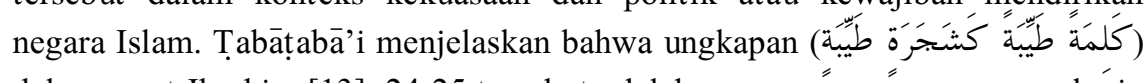
dalam surat Ibrahim [13]: 24-25 tersebut adalah perumpamaan seorang mukmin yang istiqāmah dengan tauhidnya. Sebagai mufassir dengan corak penafsiran teks dengan teks, maka Tabātabā'i mengemukan banyak ayat yang mendukung pendapatnya. Kalimat (أَصْلُهَا ثَابتَ istiqāmah dengan tauhdinýa seperti sebatang pohon yang memiliki akar yang kuat dan kokoh. Penjelasan ini dipertegas oleh Tabătabā’i dengan merujuk kepada ayat selanjutnya surat Ibrahim [14]: 27.

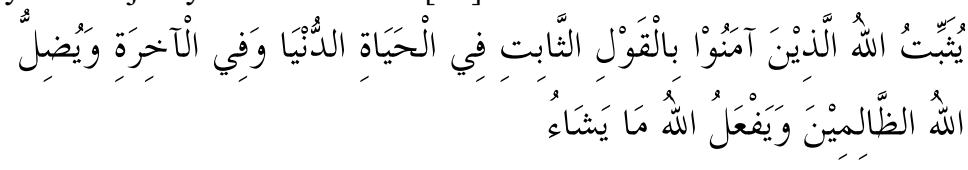

Artinya: Allah meneguhkan (iman) orang-orang yang beriman dengan ucapan yang teguh itu dalam kehidupan di dunia dan di akhirat; dan Allah menyesatkan orang-orang yang dzalim dan memperbuat apa yang Dia kehendaki.

${ }^{43}$ Ismā'îl ibn Muhammad al-Hanafi, Hashiyah al-Qunawi 'Alā Tafsìr al-Imām alBayḍawī, Juz 11 (Beirut: Dār al-Kutub al-'Ilmiyah, 2001), 60-61.

${ }^{44}$ Abu al-Qāsim Mahmūd ibn Umar al-Zamakhsharī, al-Kashshāf 'an Haqā'iq Ghawāmị̣ al-Tanzīl wa 'Uyūn al-Aqāwīl, Juz 3 (al-Riyāḍ: Maktabah al-'Abikan, 1998), 377-378. 
Lebih lanjut menurut Tạāțabā'i bahwa seorang mukmin yang istiqāmah dengan tauhidnya akan kokoh dan teguh dalam hidupnya seperti layaknya sebuah pohon dengan batang yang kokoh, akar yang menghujam dalam serta menghasilkan buah yang tiada henti sepanjang tahun. Kondisi ini akan menjadikan seorang mukmin yang istiqāmah menemukan kebahagiaan hidup tanpa ada ketakutan dan kesedihan seperti ditegaskan dalam surat Fuṣsilat [41]: 30 dan surat al-Ahquāf [46]: 13

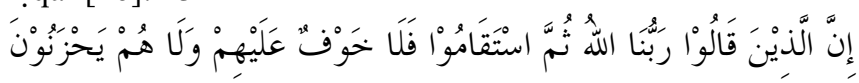

Artinya: Sesungguhnya orang-orang yang mengatakan: "Tuhan kami ialah Allah", kemudian mereka tetap istiqamah maka tidak ada kekhawatiran terhadap mereka dan mereka tiada (pula) berduka cita (Q.S. al-Ahqaf [46]: 13.

Sementara itu, kata (كَلَمَة طِيَّة kalimat tauhid berdasarkan firman Allah dalam surat fathir [35]: 10.

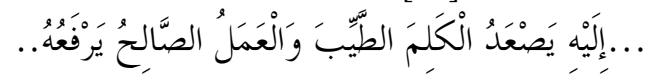

Artinya: ....Kepada-Nya lah naik perkataan-perkataan yang baik dan amal yang shaleh dinaikkan-Nya. ${ }^{45}$

Dari sekian banyak penafsiran yang dikemukakan oleh mufassir dengan beragam corak tafsir mereka, ternyata tidak satupun pendapat seperti yang dipahami atau dikemukakan oleh kelompok NII tersebut. Sementara penulis sendiri lebih cenderung dengan pemahaman umum seperti yang telah dikemukakan oleh sementara ahli tafsir. Namun menurut penulis, agaknya ayat di atas lebih bisa dipahami sebagai perumpamaan tentang sinergisitas antara akidah, syari'ah dan akhlak sebagai tiga pilar utama dalam membangun kehidupan individu dan masyarakat.

Akidah diibaratkan sebagai akar yang menghujam dalam ke perut bumi. Dengan akar yang dalam dan kokoh menjadikan pohon bisa berdiri dengan tegak dan tidak mudah roboh diterpa angin badai sekalipun. Akar yang kokoh yang menghujam dalam ke perut bumi sekaligus memungkinkannya memperoleh suplai makanan yang cukup untuk kebutuhan batang, daun dan buah sehingga proses sintesis bisa berlangsung dengan baik, dengan demikian melahirkan pohon yang rindang dan indah serta buah yang segar.

Penjelasan dari analogi ini adalah bahwa seseorang dengan akidah yang kokoh dan mantap bisa menghadang segala macam godaan dan gangguan yang datang ke padanya, baik berupa kesusahan atau bahkan kesenangan. Sekaligus,

${ }^{45}$ Muhammad Husayn al-Ṭabāṭabā'ì, al-Mizān fi Tafsìr al-Qur'ān Juz 12 (Beirut: Mu'assasat al-A'lāmì li al-Muṭbù' $\dot{\bar{u}}^{\prime}$, 1998), 48-49. 
aqidah yang benar akan menjadikan seseorang mampu menyerap nilai-nilai kebenaran yang dibutuhkan oleh jiwa untuk berbuat dan bertindak.

Sedangkan batang yang tinggi menjulang bisa dianalogikan dengan pelaksanaan syari'ah yang kokoh dan tinggi dan bermutu. Pelaksanaan syari'ah yang kokoh, tinggi dan bernilai baru bisa jika ditopang atau dilandasi oleh aqidah yang benar dan kokoh pula. Keyakinan seseorang yang kokoh akan terefleksi ke dalam amal syari'ah yang tertata dan bermutu. Begitu juga, bahwa batang yang kokoh dan bagus akan bisa menyuplai makanan yang diambil oleh akar tadi ke seluruh daun dan buah dengan baik. Dengan demikian, batang yang kokoh dan tinggi juga sangat dibutuhkan untuk bisa menghasilkan buah yang baik. Maka batang harus menjalankan tugasnya dengan baik, agar makanan yang didapatkan oleh akar tidak sia-sia dan terbuang percuma atau tertahan sampai di batang saja. Artinya syari'ah harus berjalan baik sebagai perwujudan dari akidah yang benar agar pengetahuan yang dihasilkan oleh keyakinan itu tidak sia-sia, namun teraktual dalam ibadah (praktek syari'ah). Perpaduan yang harmonis dan terintegrasi dari kedua aspek inilah yang pada gilirananya akan melahirkan akhlak atau perilaku terpuji sebagai buah dari keduanya yaitu; akidah yang kokoh dan amal syari'ah yang tinggi dan bermutu.

Sedangkan buah yang segar dan datang setiap masa adalah ibarat akhlak yang dihasilkan oleh akidah yang benar dan teraktual dalam praktek syari'ah tadi. Tidaklah ada artinya sebuah pohon dengan akar yang kokoh dan pohon yang menjulang tinggi jika tidak berbuah atau menghasilkan buah yang busuk. Seorang yang memiliki ilmu yang luas dan rajin beribadah dalam bentuk ritual tetapi tidak bisa memberikan manfaat bagi orang lain di sekitarnya, maka tentu saja akan sia-sia dan tidaklah ada artinya. Oleh karena itu, penilaian yang paling tinggi terhadap sebuah perjalanan hidup manusia adalah sejauhmana dia bernafaat bagi orang lain. Proses seseorang beragama belum lagi bisa dikatakan sempurna jika belum mampu berbuat sesuatu untuk masyarakatnya minimal memberikan manfaat dalam bentuk sikap dan prilaku terpuji.

\section{Penutup}

Mencermati penafsiran yang dilakukan oleh kelompok NII terhadap beberapa ayat al-Qur'ān bisa disimpulkan bahwa penafsiran yang dilakukan kelompok NII terhadap sebagian ayat-ayat al-Qur'ān cenderung kontektualis namun dengan menggunakan pendekatan logis yang bervisi politis (ra'yun siyāsiyun). Penafsiran al-Qur'ān dengan pendekatan ini akan menghasilkan pemahaman yang tendensius, parsial dan bahkan cendrung memaksakan suatu agar sesuai dengan ideologi penafsir sendiri. Ayat-ayat al-Qur'ān melalui 
pendekatan al-ra'yu al-siyāsiy selalu berpotensi menggiring ayat yang ditafsirkan untuk disesuikan dengan ideologi yang diperjuangkan penafsir. Namun, menvonis hasil tafsir dengan pendekatan ini sebagai suatu kesesatan agaknya juga bukan suatu sikap yang bijaksana. Perlu kedewasaan sikap untuk menerima kenyataan itu sebagai dinamika pemikiran umat Islam yang pada gilirannya akan menjadikan khazanah pemikiran Islam semakin dinamis dan kaya.

\section{Daftar Pustaka}

Abdat, Abdul Halim bin Amir. Risalah Bid'ah. Jakarta: Pustaka Abdullah, 2010. Ausop, Asep Zainal. Ajaran dan Gerakan NII KW IX\& Ma'had al-Zaytun. Bandung: Tafakur, 2011.

Ausep, Asep Zaenal "Demokrasi dan Musyawarah Dalam Pandangan Darul Arqam, NII dan Hizbut Tahrir Indonesia", Jurnal Sosioteknologi, Edisi 17 Tahun 8, Agustus (2009).

Azra, Azyumardi. "Bali and Southeast Asian Islam: Debunking the Myths", di Kumar Ramakrishna dan See Seng Tan (Editor), After Bali: The Threat of Terrorism in Southeast Asia (Singapore: Institute of Defence and Strategic Studies, Nanyang Technological University, 2003.

Bruinessen, Martin van. "Divergent Paths From Gontor: Muslim Educational

Reform and The Travails of Pluralsm in Indonesia" dalam Pak Karel, Pesantren, and Pluralism. Jurnal Penelitian Kependidikan, Tahun 16, Nomor 1, (Juni 2006).

Budiyanto, Sidik. Mewaspadai NII Zaytun di Kampus Kita. Jakarta: Kalamnet Publishing, 2006.

Carnegie, Paul J. "Political Islam and Democratic Change in Indonesia" Journal of Asian Social Science, Vol. 4, No 11 (November 2008).

al-Dimashqī, Abu al-Fidā' Ismā'īl ibn Umar ibn Kathīr al-Qurashì. Tafsìr alQur'ān al-'Azīm, Juz 4. al-Riyāọ: Dār al-Ṭibbiyah li al-Nashr wa alTawzi', 1999.

Formichi, Chiara. "Pan-Islam and Relegious Nationalism: the Case of Kartosuwiryo and Negara Islam Indonesia", Indonesia, The Journal is Published by Cornell University's Southeast Asia Program, Vol 90 (Oktober 2010).

Jaiz, Hartono Ahmad. Aliran dan Paham Sesat di Indonesia. Jakarta: Pustaka alKautsar, 2002. 
Hadi, Mahatma, dkk. Negara Islam Indonesia; Fakta Sejarah dan Perkembangannya. Jakarta: FH Universitas Indonesia, 2005.

Hamid, Ahmad Fauzi Abdul. Repoliticisation of Islam in Southeast Asia. Singapore: Bertelsmann Stiftung, 2009.

al-Hanafi, Ismā'il ibn Muhammad. Hashiyah al-Qunawi 'Alā Tafsì al-Imām alBayḍ̂wī, Juz 11. Beirut: Dār al-Kutub al-'Ilmiyah, 2001.

Heiduk, Felix. "Between a Rock and Hard Place: Radikal Islam in PostSoeharto Indonesia", International Journal of Conflict and Violence, Vol 6 (1) (2012).

Lee, Jeff. "The Failure of Political Islam in Indonesia: A Historical Narrative, Stanford Journal of East Asian Affairs, Vol, 4. Number 1, (Winter 2004).

Noor, Farish A., Yoginder Sikand \& Martin van Bruinessen (eds), The Madrasa in Asia: Political Activism and Transnational Linkages. Amsterdam: Amsterdan University Press, 2007.

NII KW IX, al-Islam, tt.

NII KW IX, Pedoman Tazkiyah, tt.

Salam, Suroso Abdul. NII dalam Timbangan Aqidah. Jakarta: Pustaka alKautsar, 2000.

Sukanto, "Membedah Gerakan Negara Islam Indonesia Komandemen Wilayah IX”, Seminar Bahaya Laten NII KW IX Masuk Kampus di Universitas Sahid, 2011.

al-Ṭabari, Abu Ja'far Muhammad Jarir. Jämi' al-Bayān 'an Ta'wīl Ay alQur'ān, Juz 13. al-Qāhirah: Markaz al-Buhūth wa al-Dirāsat al-'Arabiyah wa al-Islāmiyah, 2001.

al-Tabāṭabā'ì, Muhammad Husayn. al-Mizān fi Tafsìr al-Qur'ān Juz 12. Beirut: Mu'assasat al-A'lāmì li al-Muṭū'āat, 1998.

Tim Peneliti Indonesian Institute for Society Empowerment (INSEP). AlZaytun The Untold Stories; Investigasi terhadap Pesantren Paling Kontroversial di Indonesia. Jakarta: Pustaka Alvabet, 2011.

al-Zamakhsharī, Abu al-Qāsim Mahmūd ibn Umar. al-Kashshāf 'an Haqāiq Ghawāmị̣ al-Tanzīl wa 'Uyūn al-Aqāwīl, Juz 3. al-Riyāḍ: Maktabah al'Abikan, 1998. 